\title{
The Place of Literary Writings in Fiji's Education System An Overview of Hindi Writings in Fiji
}

\author{
Ravnil Narayan* \\ School of Communication, Languages and Literature, Fiji National University, Kings Road, Ba, Fiji Islands \\ Corresponding Author: Ravnil Narayan, E-mail: ravnilnarayan@gmail.com
}

\section{ARTICLE INFO}

Article history

Received: February 12, 2018

Accepted: April 21, 2018

Published: September 01, 2018

Volume: 7 Issue: 5

Advance access: July 2018

Conflicts of interest: None

Funding: None

\begin{abstract}
The teaching of vernacular languages or mother tongues in the Pacific island countries is one of the most neglected and vulnerable areas in education. This is borne out by the results of various studies that have been conducted over the past decades on literacy writings in vernacular. To an utter dismay, day by day and year by year, the numbers of Hindi vernacular students have been considerably declining, which is having a direct repercussion on scant publication of local literally writings in Hindi language. This original article will shed some light upon the vernacular teaching and learning of Hindi language, which has a long history in Fiji's education system. What used to be one's identity is now treated as a vehicular language, only to be used for conversational purposes. The novelty of the article will also oversee the extent of Hindi language teachings, since its early inception, and the repertoire of means that were adopted to retain her true essence in safe guarding her for the future generations. So much so, the piece is also going to look upon some of the ways in which Hindi literary writings could be brought back in Fiji's current digitalised era, and what could be done to stop her from being near extinction.
\end{abstract}

Key words: Fiji Hindi, Standard Hindi, Itaukei Language, Pundit, Literary Writings

\section{INTRODUCTION}

In Fiji where Hindi and itaukei languages are used as a medium of instruction in the first three years of primary education, and is taught as a subject at an external exam level, which is years six, seven and eight, leading up to Year 13 in high schools, students do better in English than in vernacular languages. This is unambiguously noted, when students do not get to see their raw marks, and make a hue and cry of the scaled marks. Because of the current digitalised era, students are treating vernacular as a subservient language and strongly opposing to the notion that they should not be investing in it. As such, after a substantive period of time, the rate of enrollment in vernacular classes has significantly dropped with only a handful of them making it up to the three universities in Fiji. This is highly practical for Hindi classes and not for itaukei language. This piece will basically dwell upon the Hindi vernacular and how she is being treated by our students and stakeholders, who disregard this language not because of her beauty, but what she has to offer after students complete their course of study. As a direct repercussion of this, there is a continual decline of the local writer's in Hindi language in Fiji.

On the daily basis, the Hindi language is facing absolute atrocity in terms of saving her from being a dying language. Hindi language should not be seen as a vehicular language, but should be treated as a superior codified language, which can help the current technocratical generations to also convey their ideas in written paves as well. In doing so, the young budding writers will further nurture their writings in Hindi language, which will eventually help them to continue writings to an admirable level. According to a report in the Fiji Sun, dated 27 September 2017, it was mentioned, "The association is trying to promote our Hindi language, because we saw that most of our children are reluctant to take up Hindi as a school subject. They prefer English and other subjects with the perception that, if they concentrate on a vernacular subject, they will not do well in school". This statement was divulged at an oratory contest organised by the Labasa Hindi teachers' Association.

\section{RESEARCH PROBLEM}

The research problem which lies in this piece precisely states that, scant literature was available to conduct the research, so that authenticity and credibility could be added to this original paper. In yester years, very little or virtually no research was conducted on literary writings in vernacular languages, and in particular Hindi language. Even though, literal Hindi books were published, not much recognition was given to the authors on a larger platform. As a direct ramification of it, the budding writers were never in the limelight to showcase their talent in writing Hindi literal works. In other words, they were basically working in isolation, only to see their work gets published somewhere, without any high recognition being given to it. This can be seen as one of the drawbacks as why Fiji is lacking Hindi literal writer's. 


\section{Personal Experiences}

As a personal enthusiast of the acclamation being made in the prelude of this article during the oratory contest in Labasa, this was highly noticeable by me when I was completing my high school education. I vividly remember after getting my desired mark in Hindi in the Fiji Junior Examination Certificate Examination, my form teacher strongly discouraged me to take up Hindi in form 5 levels. The reason which was told to me was that, what will I do after doing Hindi? After hearing that my own teacher, who of course happened to be a Fijian of Indian descendant telling me not to take up Hindi, I was in utter startle and felt totally demotivated. She in fact persuaded me to take up Computer studies, because it was the pioneering year in which it was offered as a subject in our college. Even though, I wanted to listen to her, but my instinct was calling me from inside to take up my mother tongue and prosper in that. Well! That is exactly what happened. I ignored what my form teacher initially said and went straight to sit with all those, who were doing Hindi in the senior forms. I was really happy, simply because I loved my mother tongue. That passion, optimistic feelings, zealousness made me rather the strongest to take up Hindi as a subject till form seven level, eventually leading up to university. Today, I have no regrets that I did not take up computer, but invested in Hindi, because I am experiencing what the subject actually had to offer, when it comes to mother tongues true beauty!

Moreover, one thing which I would also like to put across to the readers is the number of students who wished to take up Hindi as a subject during my time. The number in fact plays a pivotal role here, because it is this number which was going to produce neophyte writers in the coming futures. Some fifteen years back, the Hindi classes in senior forms would see just a little over forty students sitting for the Fiji School Leaving Certificate examinations, however, now the number has drastically reduced with as low as 2 students only taking up as a subject. The question plainly lies in front of us, what is going to be the status of Hindi language, our own identity in years to come? Well, our first teachers, our parents are the most influential beings in making the right decisions for us, especially when our career path is in an utter limbo. So much so, the true potential of not doing Hindi language is over sighted by the parents, and as a consequence of this, the void tends to be left by the children in not choosing Hindi as a subject in the Fijian classrooms.

\section{FINDINGS AND DISCUSSIONS}

\section{Platform of Hindi Writer's in Fiji}

It all started during the girmit era when some number of eminent writer's stepped into the beautiful island nation of Fiji in the quest to communicate with their fellow worker's, while working in the sugarcane plantations. These writers' had vast knowledge about Hindi language, and therefore implanted the literature of pains and sorrows, which they shared by using their mother tongue, while working in the scorchy penetrable heat of the sun in the sugarcane plantations. This actually helped the workers to ease their emotions and rejoice with those, whom they left behind in India in their heart.

Through Hindi language literature, people from the state of Uttar Pradesh mainly were about to keep intact with all those who were from the minority places of India. Some of the renowned writers which are included in the platform of writers were Pundit. Kamla Prasad Mishra, Pundit.Nand Kishore, Pundit. Pratap Chandra Sharma, Pundit. Ram Samujh Prasad, Pundit. Mohan Singh Hare, Pundit. Mahabir Mitra, Pundit. Sukh Deo Prasad Muni, Pundit. Rama Narayan, Pundit. Tota Ram Sandhya, Pundit Banarsi Deo Chaturvedi, Pundit Ami Chandra, Pundit Ajodhya Prasad, Pundit Vivekanand Sharma and Pundit Gyani Das. As such, these highly influential Hindi writers had indeed left a legacy behind, but with nostalgic emotions very little or virtually none are left to carry forward their legacies of writings in Hindi language. Our children have abandoned their own identity, and have diverted their course towards things, which does not even have any identity to give in return.

\section{Yester Writings in Action}

The first Hindi book that was written and got immeasurable popularity not in Fiji, but in India as well was Fiji Dwip Mein Mere Ikkis Varsh (My 21 years in Fiji) by Pundit. Tota Ram Sanadhya in the year 1914. The book mainly had the emotions of the writer, what actually he had gone through in terms of humiliations, which the girmit system inflicted. As such, he became a staunch opponent of the atrocities and started to write about all these, which was later considered as an eye opener to many of those, who did not get to know about what was happening with the indentured labourers' in Fiji. The other book which was written by Pundit Tota Ram was Bhoot Lane Ki Katha (The story of the Ghost Lane). This book, though unpublished at that time was a humorous text, which again gained momentum and was highly looked upon by the Hindi language sentient's. Another highly influential writer was Pundit Benarsi Das Chatuvedi, who wrote a book titled Fiji ki Samasya, which was published during the post-indenture period. Unfortunately, this book and including Pundit Tota Ram Sandhye's book Fiji Dwip Mein Mere Ikkis Varsh was banned in Fiji, because it incited strikes and other inflictions by the Indians in that era.

To add on, in the year 1936, Pundit. Ram Chandra Sharma wrote a book titled Fiji's Dig dharshan (Introduction to Fiji), who was a prominent preacher of Sanatanism in Fiji. With his book, he was able to disseminate the knowledge about Fiji to all those, who were unaware of the island nation or had meager information about her. The book was mainly written in flawless Hindi, which apparently touched almost all the aspects of life of the Fiji Indians. Another book, Pravasi was published in the year 1940, which was written by Prem Narayan Aggrawal, whose main focus was to write about the problems of all Indians living in overseas (indenture systems countries). The late Pundit. Ajodhya Prasad wrote a book named Kisan Sangh Ka Ithihas was a text which was written so eloquently, and had embeddedness of Hindi and Urdu language in it. The volume was an admirable one, which contained a detailed picture of Panditji, and the 
activities of the Sangh. All the time the reader is constantly made aware of the writer's own personality and his temperamental prejudice against Kisan Sangh.

Additionally, the great preacher was born in the year 1927, when Pundit. Ami Chandra arrived in Fiji. Panditji complied the Hindi Pothis (text books), which were used and now used as a reference guide in many Indo-Fijian dominated schools. He was able to further the cause of Hindi writings in the most impeccable manner, as he wanted, as many Indians as possible to learn and write Hindi language in the most correct manner. Inspired all by himself, Panditji started to compile Hindi writings for different levels of Hindi in primary schools. All the materials that were to be used were carefully designed to be used by the right pupils at the right age. In other words, Pundit Ami Chandra laid the foundations of Hindi language to be taught in Fijian classrooms, and was considered as one of the pioneers in this field.

\section{Writer's to Reminisce}

The three most prominent writer's whose Hindi texts I will never forget, which of course I used till university are Dr. Vivekanand Sharma, Dr. Netram Sharma and Jogindar Singh Kanwal. These writers' ostentatiously showcased their works and led the Hindi language and literature towards a new dawn after the girmit era had elapsed. Dr. Vivekanand Sharma, while studying in India wrote a book of poems titled Prashaant ki Lahere (Waves of the Pacific) and received the blessings of one of the greatest poets of India, Ram Singh Dinkarji. This book was published in two parts and has been used in the Fijian classrooms for number of years. Now, it is used as a reference guide. According to Dinkarji, Vivekanand Sharma's book brought forward "indianisation", as an important linkage towards Hindi literature writings. The other books which he wrote was Jab Manavta Kaharh Uthi (When Humanity Cried with Pain) and Fiji Ke Pradhaan Mantri (Prime Minister of Fiji). Both of these texts were lucidly written.

On the other hand, Dr. Netram Sharma was equally a stirring writer in whatever he wrote. Some of his works included Hindi Bhasha Aur Vyakaran Abyaas (Hindi Language and Grammar), Vedic Prathana Pustak (Vedic Prayer Book), Meri Maulik Rachanaye (My Local Creations) and Vedic Dharm ke Paach Kadam (Five Steps of Vedic Religion). Of all his writing, prominence was gained by Hindi Bhasha Aur Vyakaran Abyaas (Hindi Language and Grammar), as this book was used as a prescribed text in forms three and four in the Fijian high schools. Because there was a lack of local writers after those who left during the girmit era, people like Dr. Netram Sharma's work was given a high importance, due to the fact he was the very own local writer. Also, with his area of impeccable expertise towards Hindi writings, Dr. Netram Sharma was seen as a heavenly panacea towards the future development and growth of Fiji's Hindi language writings.

The next writer who has immensely contributed and highly loved his identify was Jogindar Singh Kanwalji. Kanwalji's extensive contribution towards Hindi language and writings, until this year was beyond description. He was regarded as the epitome of Hindi writings, in particular literature, in this current digitalised era. Some of his widely used writings include, Dharti Meri Maata (Earth is my Mother), Mera Desh, Mere Log (My Country, My People), Savera (The Morning), and many more trivial, yet heart touching writings in Hindi medium. Two of his above mentioned texts Dharti Meri Maata (Earth is my Mother) and Savera (The Morning) are now being used as a prescribed text in forms three and four respectively. Kanwalji was laid to rest on 17 July, 2017.

\section{The Writings of Local Dailies in Fiji}

As time went by, Hindi newspapers were taken on board to teach and preach the identity of mother tongue. Hence, in whatever form and quality they were printed, they definitely created stint in the air, particularly for all those who were illiterate or semi-literate and were mainly living in the rural Indian communities. The first newspaper published in Fiji in Hindi language was translated version of English newspaper paper titled The Settler's. Because of the great demand of readers of Hindi paper, Pundit Shiv Datt Sharma under his impeccable supervision translated the writings of English newspaper, so that no one was deprived from reading and enhancing their personal development through the use of their mother tongue. The other papers which were published in the year 1920's were, Fiji Samachar, Bharat Puttar, Vridhi and Vridhvani. Fiji Samachar was first published in the year 1923, which served the nation until 1975. During the next two decades, two more monthly dailies were published. These were Vedak Sandesh and Sanatan Dharm.

As time elapsed, The Fiji Times and Herald started to print their own weekly paper. The most significant Hindi newspaper, which off course is now the only national Hindi paper is Shanti Dut. The first publication of the Shanti Dut was in the year 1935. Although it did not fully represent the views of Indian communities at that time, it was more informative than other papers during that time. In fact, it did not have large circulation in the beginning, but gradually the number significantly escalated. Today, Shanti Dut is in circulation, but the target readers have ominously declined. It is the paper for the oldies and not for younger technocratical generations, as they do not know how to read and write their own mother tongue (that is what most of them say, when I have asked, if you know how to read and write Hindi). Other than Shanti Dut in the 1935's and onwards, some of the other monthly and weekly dailies were also printed, but overtime could not maintain its popularity amongst the readers. These publications included Kisan by Pdt. B D Lakshman, Deen Bandhu by Akhil, Fiji Krishak Maha Sangh, Gyan and Tara by Gyani Das, Pustkalyia by Arya Pustkaliya, Pravasani by Kashni Ram Kumud and Prakash by Ram Khilawan. These entire writers' published their work between the years 1935 to 1958 .

\section{Present Day Scenarios}

The future of present day writings in Hindi is at absolute brink of extinction. Looking at the number of writings in 
yester years, it could be summed that in years to come, the young generations will only get to know their second language, while their own identity will leave them. Today, it is a shame on most of the Indian dominated schools that they do not want to offer Hindi as a subject. Those one or two who actually want to take up the subject are in fact deprived and forced to take some other majors. This is absolutely erroneous! How can we try to improve the future writings in Hindi literacy studies, when our own people are trying to tarnish and jeopardize the language? In this era, students do not want to at least take initiative to read Hindi so that they could write it as well. They would rather want to say, that they are not bothered about the language, forget even writing anything about it!

So much so, the parents are also strongly discouraging their child to take up Hindi, as it is not going to lead them anywhere! The three universities in Fiji, namely University of the South Pacific, Fiji National University and University of Fiji are also struggling to get more students to take up Hindi as a major. The direct repercussion of this comes from virtually no students taking Hindi in high schools.

On the other hand, if a comparative analysis could be done, the natives are taking more pride in their language, as the student intake at these universities are skyrocketing, who are choosing itaukei language, as one of their major programmes. In brief, the children should be highly prowessed to take up Hindi language and literature, as this will surely help them to write their thoughts and feelings better using their own mother tongue. The administrators should be highly supportive and proactive here, as they are the ones who make the decision in the school systems.

\section{Languages Policy}

At the moment, Fiji does not have a language policy, by that I mean, nothing is there in black and white clearly stipulating about the status of all the languages that needs to be taught in Fijian classrooms. According to the 2000 report of the Fiji Islands Education Commission, it is not surprising that many countries including Fiji do not have any coherent language policy. Most of the decisions about language teaching and learning are made somewhat arbitrarily. Language policy and planning should be viewed as a deliberate effort to influence the attitudes of citizens with respect to language instruction. The colonial administration saw English language as the language of elite, and they only highly regarded it to be used for social and political cohesions. Thus, English turned out to be an instrument of the formation of the political community in Fiji and hence nation making. As such, this growth of political consciousness was in contradiction to the colonial policy of separate ethnic development that consolidated the status of the vernacular languages.

According to Subramani (2000), a major development in language policy, which seemed like a significant step forward, occurred as a result of constitutional modification in 1997. The constitution gave recognition to all the three national languages; however the reality was something else.
English was mainly used for government's day to day functioning, while Hindi and itaukei languages was put aside, only to be used when there was a dire need to reach the people by the means of their mother tongue. None the less, a language policy that seeks to balance the dual projects of national cohesion and language diversity has value in sustaining national development, and therefore, needs the support of the civil society groups and the government as a whole.

\section{Concluding Remarks}

The future for Hindi writings and publications in Fiji are highly questionable. With only a handful of the young buds taking it up to the next level, this is highly detrimental. As such, the market for Hindi literary writings and publications is going to be narrow. Despite this problem, the Hindi writings must be prowessed through various means. The right should be given by the respective stakeholders to rethink about investing in Hindi literary writings. Looking at the yester year's writers, they did so much to safeguard their mother tongue, and preach about it. In this current era, what are our technocrats doing? Now that they even have the technology sitting right on their palm, there is unquestionably a huge potential to write texts in their own mother tongue. What used to be the pride of our forefather's will be left abandon, if no quick action is going to be initiated.

Parents should start rethinking about making their children learn Hindi language and literature, so that these children can invest in writings, as much as possible in Hindi. It is highly imperative that the mother tongue must be given an optimum respect and encouragement. By doing so, the child will feel a sense of security and highly motivated in doing whatever, which requires the use of mother tongue in it. So much so, the budding local writers should be brought forward to the national platform to showcase their talents to others, so that they are motivated, and start writing in Hindi with whatever flaws they have. After all, a humble beginning starts with a lot of jolts and glitches. Also, a national language policy should be designed so that vernacular languages true status could be put into practice, and not be treated as subservient languages.

A high regard in the implementation to promote vernacular writings, in particular Hindi language would see a change in people's perception on the language itself. As such, just like early post-indenture years, Fiji may see a reborn of more monthly and weekly dailies in Hindi language literary writings, with reflections of it only to pursue, as generations by generations will come and go.

\section{REFERENCES}

Kanwal.J.S. (1980), A Hundred Years of Hindi in Fiji, Universal Printing Press Limited, Suva.

Ministry of Education, (2000), Learning together: directions for education in the Fiji Islands, Government Printery, Suva.

Subramani. (2000). Indo-Fijian writing. Journal of Postcolonial Writing, 27(1), pp.143-151. 